\title{
CENTRIFUGAL PARTITION CHROMATOGRAPHY (CPC) - A NOVEL METHOD OF SEPARATION AND PURIFICATION OF NATURAL PRODUCTS - A SHORT REVIEW
}

\author{
Simona Spînu ${ }^{1,2}$, Alina Ortan ${ }^{1, *}$, Daniela Ionescu ${ }^{1,3}$, Ionuţ Moraru ${ }^{4}$ \\ ${ }^{1}$ University of Agronomic Sciences and Veterinary Medicine of Bucharest, \\ 59 Mărăşti Blvd., 011464, Bucharest, Romania \\ ${ }^{2}$ University of Bucharest, Faculty of Physics, Doctoral School of Biophysics and Medical Physics, \\ 405 Atomiștilor Str., 077125, Măgurele, Ilfov, Romani. \\ ${ }^{3}$ Hofigal Export Import S.A., 2 Intrarea Serelor Str., 042124, Bucharest, Romania \\ ${ }^{4}$ S.C. Laboratoarele Medica S.A., Otopeni, Romania
}

\begin{abstract}
As technology has evolved, the field of liquid chromatography has developed, bringing new, alternative and high level methods of separation, isolation and purification of the natural products present in the natural plant extracts, replacing the traditional chromatographic methods. In this direction, until now, it has been observed that the Centrifugal Partition Chromatography $(C P C)$ presents a high precision in isolating the individual compounds. Thus, we chose to study this topic in the present review. Currently, there is a growing interest in the use of CPC in the sustainable isolation and purification of cannabidiol (CBD) from Cannabis plants due to the extensive medical benefits of cannabis compounds (i.e. epilepsy, multiple sclerosis, etc.); atractylenolide I, selina4(14),7(11)-dien-8-one and (6E,12E)tetradeca-6,12-diene-8,10-diyne-1,3-diol diacetate from Atractylodis Rhizoma Alba; xylindein from Chlorociboria aeruginosa; diphlorethohydroxycarmalol and octaphlorethol A from Ishige okamurae;Caulerpenyne from Caulerpa taxifolia, etc., most of them with antitumoral activities. Therefore, the challenge of the researchers is to obtain natural compounds through optimization protocols (including columns, sample properties in the solvent system, physical properties of the stationary and mobile phase, parameters of the instrument, etc.), saving time and in an economically cheaper manner. In conclusion, it can be stated that CPC is superior to the traditional methods, extracting compounds faster with high purity (99\%), with a higher recovery rate (95\%); also, it is environmentally sustainable, contributing efficiently to the pharmaceutical industry development.
\end{abstract}

Keywords: Centrifugal Partition Chromatography (CPC), natural products purification, separation.

\section{INTRODUCTION}

One of the most recently used and advanced techniques in liquid-liquid chromatography is centrifugal partition chromatography (CPC). It is a technique derived from counter-current chromatography, being also known as Hydrostatic Countercurrent Chromatography (HCC) (Foucault, 1995). Today, the purification of natural compounds present in the natural plant or fruits extracts is a complex process, which involves the usage of techniques and devices with high precision in separating and isolating the individual bioactive compounds. CPC is a novel technique which brings bright results in separation, isolation and purification of natural liquid extracts 
mixtures, in a shorter time. This procedure is not using a silica column or support media, but two immiscible liquid phases (mobile and stationary phases) (Berthod et al., 2015). The partition between this two immiscible phases of a solvent system is the main principle of the CPC. The centrifugal field created keeps the stationary phase in the column, when the rotor starts to spin. The stationary phase is distributed and retained inside of the rotor and the mobile phase which contains the solutes to be extracted is pumped through under pressure as a mobile phase, crossing through stationary phase (Berthod et al., 2015). Based on the partition coefficients (KD) and selectivity ( $\alpha$ ), the solutes present in the mobile phase inside the CPC (rotor) column are separated and isolated. The partition coefficient represents a ratio between the solutes concentration in the stationary and mobile phases. This may explain the fact that the mixture compounds with higher affinity for the mobile phase are eluting earlier than others with higher affinity for stationary phase.

Researchers are working on the optimization protocols, using all the advantages of the CPC compared with the traditional separation techniques, including: the low solvent consumption; performance, purity and recovery at high levels; a low running time at a high flow rate; the impossibility of denaturation and sample loss.

The aim of this review paper is to conduct a literature study using public libraries, which contain research articles from the last 5 years (2016 - present). This is a review of research on the optimization protocols and bioactive compounds types separated, isolated and purified from synthetic compunds mixtures and/or plant and fruits material by CPC. First of all, the breaf CPC principles will be presented regarding the operation modes and optimisation steps, as well as the components. More, will be presented the biphasic solvent system types, best fitted, acoording to the researchers' works. Finally, a review of the recently conditions and examples of isolation, separation and purification of bioactive compounds by CPC from synthetic compounds mixtures and/or plant and fruits material os presented.

\section{BRIEF CPC PRINCIPLES}

\subsection{Brief CPC device description}

A CPC device has many advantages as: high recovery of the sample, various types of solvent systems, shorter running time, high injection volume and easy scale-up. A CPC system works as a preparative LC column, analogous to a preparative high performance liquid chromatography (HPLC) column, and its main components are the rotor (or column) and the rotary seals. Generally a CPC rotor is composed of individual disks, which contains twin cells linked by channels. Inside of the twin cells the liquid stationary phase is retained. Both sides of each twin cell have channels for the entrance and the exit of the mobile-phase.

\subsection{Operation modes}

The CPC operation modes are two, the ascending mode and the descending mode. In the ascending mode the lightest/upper phase is the mobile phase, and in the descending mode the heaviest/lower phase is the mobile phase. There is the possibility to change the flow direction during the process and to operate in dual-mode, ascending mode mixed with descending mode or vice-versa. In order to occur the separation the $\mathrm{K}_{\mathrm{D}}$ is ranged between 0.5 and 5 (Marlot et al., 2017). If the $\mathrm{Kd}$ value is lower then 0.5 there is no separation and the analyte is retained in the mobile phase. In the opposite case, $K_{D}$ value is higher then 5 , the analyte is retained in the stationary phase. Therefore, an extremely important step in operating the CPC is the selection of solvent system. 


\subsection{Optimization steps in CPC}

Optimization processes involve a number of mechanical, chemical and temporal factors. Most common factors are: rotational speed, flow rate, solvent system, elution step duration and extrusion step duration. These factors depend on the operation mode selected. The solvent systems can be optimized using the Arizona phase system family or trying different experimental conditions.

In order to optimize the purification process studies reported the usage of strong ion exchange CPC (IX-CPC) (Boudesocque et al., 2017).

The separation and isolation processes are influenced by parameters as sample properties (partition coefficients of the molecules, bio-active compounds concentration), solvent system (interfacial tension, densities, viscosities), instrument (shape, volume, cells material, size) and method (operation mode, flow rate, rotational, injection volume) (Bojczuk et al., 2017).

\section{BIPHASIC SOLVENT SYSTEM}

As mentioned before, biphasic solvent systems selection is an important step in the CPC separation. The most used solvents are heptane, ethyl acetate, methanol and water. There are several studies that have used biphasic solvent systems based on deep eutectic solvents for the separation and isolation of compounds from a mixture (Bezold et al., 2017). For a better solvent system selection, Bezold et all. proposed (Bezold et al., 2017) the predictive thermo-dynamic model COSMO-RS (Conductor-like Screening Model for Realistic Solvation).

The most common types of biphasic solvent systems for CPC contain a mixture of three or four solvents, as Arizona phase system composed of heptane (or hexane), ethyl acetate, methanol and water; the Oka scale composed of hexane, ethyl acetate, n-butanol, methanol, and water; and the acetone scale which is composed of heptane, toluene, acetone, and water (Boonloed et al., 2016). The biphasic solvent systems found in the research are listed in Table 1.

\section{ISOLATION, SEPARATION AND PURIFICATION OF BIOACTIVE COMPOUNDS BY CPC FROM SYNTHETIC COMPUNDS MIXTURES AND/OR PLANT AND FRUITS MATERIAL.}

Isolation, separation, recovery and purification of bioactive compounds by CPC are important tools in nowadays researches. The bioactive-compounds isolated, recovered, purified or separated by CPC methods are presented in the Table 1.

During the last years, the CPC is intense applied in various fields, and a study conducted by Phansalkar (Phansalkar et al., 2018) reports the fact that CPC enabled selective enrichment of trimeric and tetrameric proanthocyanidins for biomaterial development.

Tabel 1. Isolation, separation and purification of bioactive compounds by CPC

\begin{tabular}{|c|c|c|c|}
\hline Biphasic solvent system & $\begin{array}{l}\text { Ratio } \\
(v / v)\end{array}$ & $\begin{array}{l}\text { Isolation/ } \\
\text { Separation/ } \\
\text { Fractionation/ } \\
\text { Purification }\end{array}$ & Compounds \\
\hline $\begin{array}{l}\text { n-Heptane/Ethanol/Choline } \\
\text { chloride - levulinic acid }\end{array}$ & $1 / 1.33 / 1$ & \multirow[t]{2}{*}{ separation } & \multirow{2}{*}{$\begin{array}{l}\alpha, \gamma-\text { tocopherol from } \\
\text { tocopherol mixture (Bezold } \\
\text { et al., 2017). }\end{array}$} \\
\hline $\begin{array}{l}\text { n-Heptane/Ethanol/Choline } \\
\text { chloride - 1,4-butanediol }\end{array}$ & $1 / 1.33 / 1$ & & \\
\hline Methyl $\quad$ tert-butyl & $2 / 1 / 2 / 5$ & purification & dirucotide \\
\hline
\end{tabular}


Current Trends in Natural Sciences

Vol. 9, Issue 18, pp. 06-11, 2020

https://doi.org/10.47068/ctns.2020.v9i18.001

Current Trends in Natural Sciences (on-line)

ISSN: 2284-953X

ISSN-L: 2284-952
Current Trends in Natural Sciences (CD-Rom) ISSN: 2284-9521

\begin{tabular}{|c|c|c|c|}
\hline $\begin{array}{l}\text { ether/Acetonitrile/ } \\
\text { Butanol/Water }\end{array}$ & & & $\begin{array}{l}98 \% \text { purity) from dirucotide } \\
84.3 \% \text { (Boudesocque et al., } \\
2017 \text { ). }\end{array}$ \\
\hline Methanol/n-Hexane/Water & $5 / 5 / 0.8$ & $\begin{array}{l}\text { isolation, } \\
\text { purification }\end{array}$ & $\begin{array}{l}\text { valtrate and 7-homovaltrate ( } \\
97 \% \text { ) from Centranthus ruber } \\
\text { L. Roots (Chami et al., 2018). }\end{array}$ \\
\hline Methyl tert-butyl ether/Water & $1 / 1$ & fractionation & $\begin{array}{l}\text { water soluble phase of a fast } \\
\text { pyrolysis bio-oil (Dubuis et } \\
\text { al., 2019). }\end{array}$ \\
\hline $\begin{array}{l}\text { Heptane/Ethyl } \\
\text { acetate/Methanol/Water }\end{array}$ & $1 / 2 / 1 / 2$ & separation & $\begin{array}{l}\text { fast pyrolysis oil produced } \\
\text { from softwood sawdust (Le } \\
\text { Masle et al., 2018). }\end{array}$ \\
\hline $\begin{array}{l}\text { n-Hexane/Ethyl acetate/ } \\
\text { Ethanol/Water }\end{array}$ & $8 / 2 / 5 / 5$ & $\begin{array}{l}\text { isolation } \\
\text { purification }\end{array}$ & $\begin{array}{l}\text { Acidic cannabinoids (>45\% } \\
\text { recovery; }>95 \% \text { purity) from } \\
\text { Cannabis sativa L. (Popp et } \\
\text { al., 2019). }\end{array}$ \\
\hline $\begin{array}{l}\text { n-Heptane/Ethyl acetate/ } \\
\text { Methanol/Water }\end{array}$ & $\begin{array}{l}4 / 1 / 4 / 1 \\
\text { (Arizona } \\
\mathrm{U})\end{array}$ & purification & $\begin{array}{l}\text { Caulerpenyne from Caulerpa } \\
\text { taxifolia (Sfecci et al., 2017). }\end{array}$ \\
\hline $\begin{array}{l}\text { n-Heptane/Ethyl } \\
\text { Methanol/Water }\end{array}$ & $\begin{array}{l}\text { Arizona } \\
\mathrm{K}-\mathrm{Q} \text { and } \\
\mathrm{T}-\mathrm{Z}\end{array}$ & fractionation & $\begin{array}{l}\text { Enrichment of anthraquinones } \\
\text { from Kniphofia uvaria seeds } \\
\text { (Duval et al., 2016). }\end{array}$ \\
\hline $\begin{array}{l}\text { n-Heptane/Tetrahydrofuran/ } \\
\text { Methyl ethyl } \\
\text { ketone/Acetonitrile/Acid } \\
\text { acetic/Water }\end{array}$ & $\begin{array}{l}2 / 5 / 2 / 2 / \\
0.1 / 2\end{array}$ & $\begin{array}{l}\text { isolation } \\
\text { purification }\end{array}$ & $\begin{array}{l}\text { Xylindein from Chlorociboria } \\
\text { aeruginosa (Boonloed et al., } \\
\text { 2016). }\end{array}$ \\
\hline Toluen/Acetonitrile/Water & $4 / 1 / 5$ & purification & $\begin{array}{l}\text { Catharanthine and vindoline } \\
\text { from aerial parts of } \\
\text { Catharanthus roseus (Kotland } \\
\text { et al., 2016). }\end{array}$ \\
\hline Heptane/Methanol/Acetonitrile & $6 / 1 / 2$ & $\begin{array}{l}\text { separation } \\
\text { purification }\end{array}$ & $\begin{array}{l}\text { Pyrethrins (99\%) (Pyrethrin I, } \\
\text { cinerin I, jasmolin I) from } \\
\text { flowers of Chrysanthemum } \\
\text { cinerariaefolium (Wong and } \\
\text { Glinski, 2017). }\end{array}$ \\
\hline $\begin{array}{l}\text { Heptane/Terbutylmethyl } \\
\text { ether/Acetonitrile/Water }\end{array}$ & $8 / 1 / 5 / 1.5$ & $\begin{array}{l}\text { separation } \\
\text { purification }\end{array}$ & $\begin{array}{l}\text { Pyrethrins (99\%) (Pyrethrin } \\
\text { II, cinerin II, jasmolin II) } \\
\text { from } \\
\begin{array}{l}\text { Chrysanthemum } \\
\text { cinerariaefolium (Wong and } \\
\text { Glinski, 2017). }\end{array}\end{array}$ \\
\hline $\begin{array}{l}\text { n-Hexane/Ethyl } \\
\text { acetate/Methanol/Water }\end{array}$ & $8 / 2 / 8 / 2$ & $\begin{array}{l}\text { isolation } \\
\text { purification }\end{array}$ & $\begin{array}{l}\text { (6E,12E)-tetradeca-6,12-dien- } \\
\text { 8,10-diyne-1,3-diyl diacetate, } \\
\text { atractylenolide I, selina- }\end{array}$ \\
\hline
\end{tabular}




\section{Current Trends in Natural Sciences}

Vol. 9, Issue 18, pp. 06-11, 2020

https://doi.org/10.47068/ctns.2020.v9i18.001

Current Trends in Natural Sciences (on-line)

\begin{tabular}{|l|l|l|l|}
\hline & & & $\begin{array}{l}\text { 4(14),7(11)-dien-8-one from } \\
\text { Atractylodis Rhizoma Alba } \\
\text { (Kim et al., 2018). }\end{array}$ \\
\hline $\begin{array}{l}\text { Heptane/Methyl ter-butyl } \\
\text { ether/Ethanol/Water }\end{array}$ & $4 / 1 / 4 / 1$ & purification & $\begin{array}{l}\text { Carnosol from Rosmarinus } \\
\text { officinalis (Bouju et al.,2016) }\end{array}$ \\
\hline $\begin{array}{l}\text { Hexane/Ethyl } \\
\text { acetate/Methanol/Water }\end{array}$ & $3 / 2 / 3 / 2$ & purification & $\begin{array}{l}\text { Carnosic acid (96.1 } \pm 1 \% \text { ) } \\
\text { and carnosol (94.4 } \pm 0.9 \%) \\
\text { from Rosmarinus officinalis } \\
\text { (Grace et al., 2017). }\end{array}$ \\
\hline Toluene/Acetic acid/Water & $30 / 24 / 50$ & $\begin{array}{l}\text { separation } \\
\text { purification }\end{array}$ & $\begin{array}{l}\text { Aflatoxins produced by } \\
\text { Aspergillus parasiticus and } \\
\text { Aspergillus flavus (Endre et } \\
\text { al., 2019). }\end{array}$ \\
\hline Methyl ter-butyl ether/Water & $1 / 1$ & $\begin{array}{l}\text { isolation } \\
\text { purification }\end{array}$ & $\begin{array}{l}\text { Leontopodic acid A and 3,5- } \\
\text { dicaffeoylquinic } \\
\text { acid from Edelweiss plant } \\
\text { extract (Marlot et al., 2017). }\end{array}$ \\
\hline $\begin{array}{l}n \text {-Hexane/Ethyl } \\
\text { acetate/Ethanol/Water }\end{array}$ & $8 / 2 / 8 / 2$ & $\begin{array}{l}\text { separation } \\
\text { isolation }\end{array}$ & $\begin{array}{l}\text { 9-hydroxy isoegomaketone, } \\
\text { isoegomaketone, perilla } \\
\text { ketone from Perilla frutescens } \\
\text { var. crispa leaves extract } \\
\text { (Nam et al., 2019). }\end{array}$ \\
\hline $\begin{array}{l}\text { Hexane/Ethyl } \\
\text { acetate/Methanol/Water }\end{array}$ & $1 / 9 / 1 / 9$ & isolation & $\begin{array}{l}\text { Proanthocyanidins from } \\
\text { avocado peels (Torres et al., } \\
\text { 2018). }\end{array}$ \\
\hline
\end{tabular}

\section{CONCLUSIONS}

CPC represents a reproducible and robust technique for large-scale separation. The CPC method is developed for the preparative scale purification of bioactive compounds from mixtures of compounds. In the field of the drug development, natural products still contribute maintaining the interest of researchers for their isolation and purification.

\section{ACKNOWLEDGEMENTS}

The authors gratefully acknowledge the support obtained through the project SusMAPWaste, SMIS 104323, Contract No. 89/09.09.2016, from the Operational Program Competitiveness 2014-2020, project co-financed from the European Regional Development Fund.

\section{REFERENCES}

Berthod, A., Faure, K. (2015). Separations with a liquid stationary phase: countercurrent chromatography or centrifugal partition chromatography. Anal. Sep. Sci., 1177-1206.

Bezold, F., Weinberger, M.E., Minceva, M. (2017). Computational solvent system screening for the separation of tocopherols with centrifugal partition chromatography using deep eutectic solvent-based biphasic systems. $J$. Chromatogr. A, 1491, 153-158.

Boonloed, A., Weber, G.L., Ramzy, K.M., Dias, V.R., Remcho, V.T. (2016). Centrifugal partition chromatography: A preparative tool for isolation and purification of xylindein from Chlorociboria aeruginosa. J. Chromatogr. A, $1478,19-25$ 


\section{Current Trends in Natural Sciences}

Vol. 9, Issue 18, pp. 06-11, 2020

https://doi.org/10.47068/ctns.2020.v9i18.001

Current Trends in Natural Sciences (on-line)

ISSN: 2284-953X

Current Trends in Natural Sciences (CD-Rom)

ISSN: 2284-9521

ISSN-L: 2284-9521

ISSN-L: 2284-9521

Boudesocque, L., Forni, L., Martinez, A., Nuzillard, J.M., Giraud, M., Renault, J.H. (2017). Purification of dirucotide, a synthetic 17-aminoacid peptide, by ion exchange centrifugal partition chromatography. J. Chromatogr. A, 1513, 78-83.

Bouju, E., Berthod, A., Faure, K. (2016) Carnosol purification. Scaling-up Centrifugal Partition Chromatography Separations. J Chromatogr A., 1466, 59-66.

Bojczuk, M., Żyżelewicz, D., Hodurek, P. (2017). Centrifugal partition chromatography - A review of recent applications and some classic references. J. Sep. Sci., 40, 1597-1609.

Chami, M.C., Bouju, E., Lequemener, C., de Vaumas, R., Hadji-Minaglou, F., Fernandez, X., Michel, T. (2018). Purification of two valepotriates from Centranthus ruber by centrifugalpartition chromatography: From analytical to preparative scale. J. Chromatogr. A, 1580, 126-133.

Dubuis, A., Le Masle, A., Chahen, L., Destandau, E., Charon, N. (2019). Centrifugal partition chromatography as a fractionation tool for the analysis of lignocellulosic biomass products by liquid chromatography coupled to mass spectrometry. J. Chromatogr. A, 1597, 159-166.

Duval, J., Destandau, E., Pecher, V., Poujol, M., Tranchant, J.F., Lesellier, E. (2016). Selective enrichment in bioactive compound from Kniphofia uvaria bysuper/subcritical fluid extraction and centrifugal partitionchromatography. J. Chromatogr. A, 1447, 26-38.

Endre, G., Hegedüs, Z., Turbat, A., Škrbic, B., Vágvölgyi, C., Szekeres, A. (2019). Separation and Purification of Aflatoxins by Centrifugal Partition Chromatography. Toxins, 11(6):309, 1-16.

Foucault, A.J.P. (1995). Centrifugal Partition Chromatography, Marcel Dekker, NewYork, (A.J.P. Foucault).

Grace, M.H., Qiang, Y., Sang, S., Lila, M.A. (2017). One-step isolation of carnosic acid and carnosol from rosemary by centrifugal partition chromatography. J Sep Sci., 40(5), 1057-1062.

Kim, M.I., Kim, J.H., Syed, A.S., Kim, Y.M., Choe, K.K., Kim, C.Y. (2018). Application of Centrifugal Partition Chromatography for Bioactivity-Guided Purification of Antioxidant-Response-Element-Inducing Constituents from Atractylodis Rhizoma Alba. Molecules, 23, 1-10.

Kotlana, A., Chollet, S., Diard, C., Autret, J.M., Meucci, J., Renault, J.H., Marchal, L. (2016). Industrial case study on alkaloids purification by $\mathrm{pH}$-zone refiningcentrifugal partition chromatography. J. Chromatogr. A, 1474, 59-70.

Le Masle, A., Santin, S., Marlot, L., Chahen, L., Charon, N. (2018). Centrifugal partition chromatography a first dimension for biomass fast pyrolysis oil analysis. Analytica Chimica Acta, 1029, 116-124.

Marlot, L., Batteau, M., Escofet, M.C., Nuccio, S., Coquoin, V., De Vaumas, R., Faure, K. (2017). Two-dimensional multi-heart cutting centrifugal partition chromatography-liquid chromatography for the preparative isolation of antioxidants from Edelweiss plant. Journal of Chromatography A, 1504, 55-63.

Nam, B., Paudel, S.B., Kim, J.B., Jin, C.H., Lee, D., Nam, J.W., Han, A.R. (2019). Preparative Separation of Three Monoterpenes from Perilla frutescens var. crispa Using Centrifugal Partition Chromatography. International Journal of Analytical Chemistry, 3, 1-7.

Phansalkar, R.S., Nama, J.W., Chen, S.N., McAlpine, J.B., Leme, A.A., Aydin, B., Bedran-Russo, A.K., Pauli, G.F. (2018). Centrifugal partition chromatography enables selective enrichment of trimeric and tetrameric proanthocyanidins for biomaterial development. J. Chromatogr. A, 1535, 55-62.

Popp, J.R., Petrakis, E.A., Angelisa, A., Halabalaki, M., Bonn, G.K., Stuppner, H., Skaltsounis, L.A. (2019). Rapid isolation of acidic cannabinoids from Cannabis sativa L. usingpH-zone-refining centrifugal partition chromatography. J. Chromatogr. A, 1599, 196-202.

Sfecci, E., Le Quemener, C., Lacour, T., Massi, L., Amade, P., Audo, G., Mehiri, M. (2017). Caulerpenyne from Caulerpa taxifolia: A comparative study between CPC and classical chromatographic techniques. Phytochemistry Letters, 20, 406-409.

Torres, E., García, A., Aranda, M., Saéz, V., Zúñiga, F., Alarcón, J., Avello, M., Pastene, E. (2018). One-step purification of two semi-synthetic epicatechin adducts prepared from avocado peels procyanidins by centrifugal partition chromatography and evaluation of their anti-inflammatory effects on adenocarcinoma gastric cells infected with Helicobacter pylori. J. Chil. Chem. Soc., 63, 4, 4222-4228.

Wong, A., Glinski, J.A. (2017) Efficient, Baseline Separation of Pyrethrins by Centrifugal Partition Chromatography, $J$ Chromatogr Sep Tech, 8(2), 1-7. 